Indonesian Journal of Electronics and Instrumentation Systems (IJEIS)

Vol.10, No.2, October 2020, pp. 143 154

ISSN (print): 2088-3714, ISSN (online): 2460-7681

DOI: https://doi.org/10.22146/ijeis.60722

\title{
Enhanced Active Filter for Single-Phase Controlled Rectifier Applications
}

\author{
Jacob Dethan*1 ${ }^{1}$ Abidin $^{2}$, Benny Daniawan ${ }^{3}$, Rino $^{4}$ \\ ${ }_{1,2,3,4}$ Universitas Buddhi Dharma, Indonesia \\ e-mail: *1 jacob.dethan@ubd.ac.id , ${ }^{2}$ abahtea76@yahoo.com, ${ }^{3} \mathrm{~b} 3 \mathrm{n} 2 \mathrm{y}$ _miracle@yahoo.co.id, \\ ${ }^{4}$ mr.rino85@gmail.com
}

\begin{abstract}
Abstrak
Filter aktif dapat digunakan untuk meningkatkan kinerja penyearah terkontrol satu fasa dengan mengurangi riak yang dihasilkan dan distorsi harmonik. Filter aktif juga dapat meningkatkan faktor daya dan efisiensi thyristor. Pada penelitian ini, filter aktif dirancang dengan menggunakan NPN Bipolar Junction Transistor (BJT) dibandingkan dengan filter aktif yang dibuat dengan memanfaatkan NPN Metal Oxide Semiconductor Field Effect Transistor (MOSFET). Efisiensi filter aktif berbasis BJT dengan sudut penyalaan $0^{\circ}$ hingga $90^{\circ}$ diperoleh efisiensi sebesar 87,01\% - 96,67\%. Sedangkan filter aktif berbasis MOSFET menghasilkan efisiensi yang sebanding antara 90,62\% - 96,07\%. Terlihat bahwa filter aktif berbasis MOSFET menghasilkan efisiensi yang lebih tinggi pada sudut penyalaan $0^{\circ}$ yaitu $90,62 \%$ dibandingkan filter aktif berbasis BJT yang menghasilkan efisiensi 87,01\% pada sudut penyalaan yang sama. Kedua filter aktif memperoleh faktor daya yang hampir sama dalam kisaran 0,57 tertinggal 0,92 tertinggal. Diharapkan bahwa penelitian ini dapat bermanfaat untuk perancangan filter aktif untuk berbagai aplikasi elektronika daya termasuk perancangan sistem transmisi daya High Voltage Direct Current (HVDC).
\end{abstract}

Kata kunci-BJT, MOSFET, filter aktif, efisiensi

\begin{abstract}
Active filter can be used to increase the performance of single-phase controlled rectifier by reducing the generated ripple and harmonic distortion. Active filter can also increase power factor and efficiency of thyristor. In this work, active filter was designed by using NPN Bipolar Junction Transistor (BJT) compared with active filter created by utilizing NPN Metal Oxide Semiconductor Field Effect Transistor (MOSFET). The obtained efficiency of BJT based active filter with firing angles of $0^{\circ}$ to $90^{\circ}$ were $87.01 \%-96.67 \%$. Whereas, MOSFET based active filter produced comparable efficiency between $90.62 \%-96.07 \%$. It can be seen that MOSFET based active filter produced higher efficiency at firing angle of $0^{\circ}$ which was $90.62 \%$ compared to BJT based active filter that has produced efficiency of $87.01 \%$ at the same firing angle. Both active filters obtained similar power factors within the range of 0.57 lagging - 0.92 lagging. It is expected that this work can be useful for the design of active filters for various power electronics applications including the design of High Voltage Direct Current (HVDC) power transmission system.
\end{abstract}

Keywords-BJT, MOSFET, active filter, efficiency

Received October $20^{\text {th }}, 2020$; Revised October $29^{\text {th }}, 2020$; Accepted October $31^{\text {th }}, 2020$ 


\section{INTRODUCTION}

Electrical energy has now become a primary need of humans. Human dependence on technological progress cannot be separated from a stable supply of electrical energy. In the use of electronic equipment, $\mathrm{AC}$ voltage sources are often converted to DC voltages [1,2]. In this conversion process, a rectifier component is needed [3-7]. One of the rectifiers used is a singlephase controlled rectifier called thyristor $[8,9]$. Thyristor does not only operate as a rectifier but also as a gate that holds or passes the movement of electric current. However, the use of thyristors also has a negative impact on the harmonics produced. Harmonics are disruptions to the quality of electric power caused by distortion of current and voltage waveforms.

Thus, filters are required [10-15] to reduce the magnitude of the generated harmonics which are produced by rectifier. Filters not only can diminish the magnitude of harmonics but also can reduce ripple voltage and improve power factor as well as power quality produced by the rectifier. Previous works have introduced the use of filters with varying configurations. In general, filters can be classified as passive filters and active filters. In most cases, active filters are preferred [16-25] since they offer better power quality and better harmonics as well as reactive power compensation [26-33].

Bipolar junction transistor was used for the design of an active capacitance circuit and it was obtained that the circuit can replace the passive capacitors of resonators [34]. The use of BJT also proposed in the recent work of [35] where the designed filter can obtain additional noise reduction until $30 \mathrm{~dB}$ within the frequency of $150 \mathrm{kHz}$ to $3 \mathrm{MHz}$. This shows that BJT can be one of the options for the application of active filter. However, it is well known that MOSFET also has some advantages over BJT such as more tolerant to heat, more power efficient and has higher input impedance.

In this study, the performance of BJT and MOSFET will be compared to provide clear insights of how these two devices can be used as main components of active filters. It is expected the obtained results can be useful for future design of more effective and efficient active filters that can be used in various applications including the recent development of HVDC power transmission system.

\section{METHODS}

The constructed active filter is shown in Figure 1 where the position of BJT was compared by replacing it with MOSFET. The choice of capacitor with the value of $1 \mu \mathrm{F}$ was obtained using Equation (1).

$$
\mathrm{C}=\mathrm{I} \times \mathrm{T} / \mathrm{Vr}
$$

where,

I is the supplied current, $\mathrm{T}$ is the period and $\mathrm{Vr}$ is the ripple voltage.

The performance of active filter BJT vs. active filter MOSFET was analyzed by calculating important parameters. The power factor was calculated as

$$
\mathrm{PF}=\sqrt{(1-T H D)^{2}} \times \cos \varnothing
$$

The AC voltage was computed as

$$
\mathrm{V}_{\mathrm{AC}}=\sqrt{V_{R M S^{2}}-V_{D C}{ }^{2}}
$$

Then the ripple factor was calculated using the following equation

$$
\mathrm{RF}=\frac{V_{A C}}{V_{D C}} \times 100 \%
$$

IJEIS Vol. 10, No. 2, October 2020 : 143 - 154 
The output powers then computed as follows

$$
\begin{aligned}
& \mathrm{P}_{\mathrm{AC}}=\frac{V_{R M S}{ }^{2}}{R} \\
& \mathrm{P}_{\mathrm{DC}}=\frac{V_{D C^{2}}}{R}
\end{aligned}
$$

Ultimately, efficiency was calculated using equation below

$$
\eta=\frac{P_{D C}}{P_{A C}} \times 100 \%
$$

The simulation method was entirely carried out using PSPICE software.

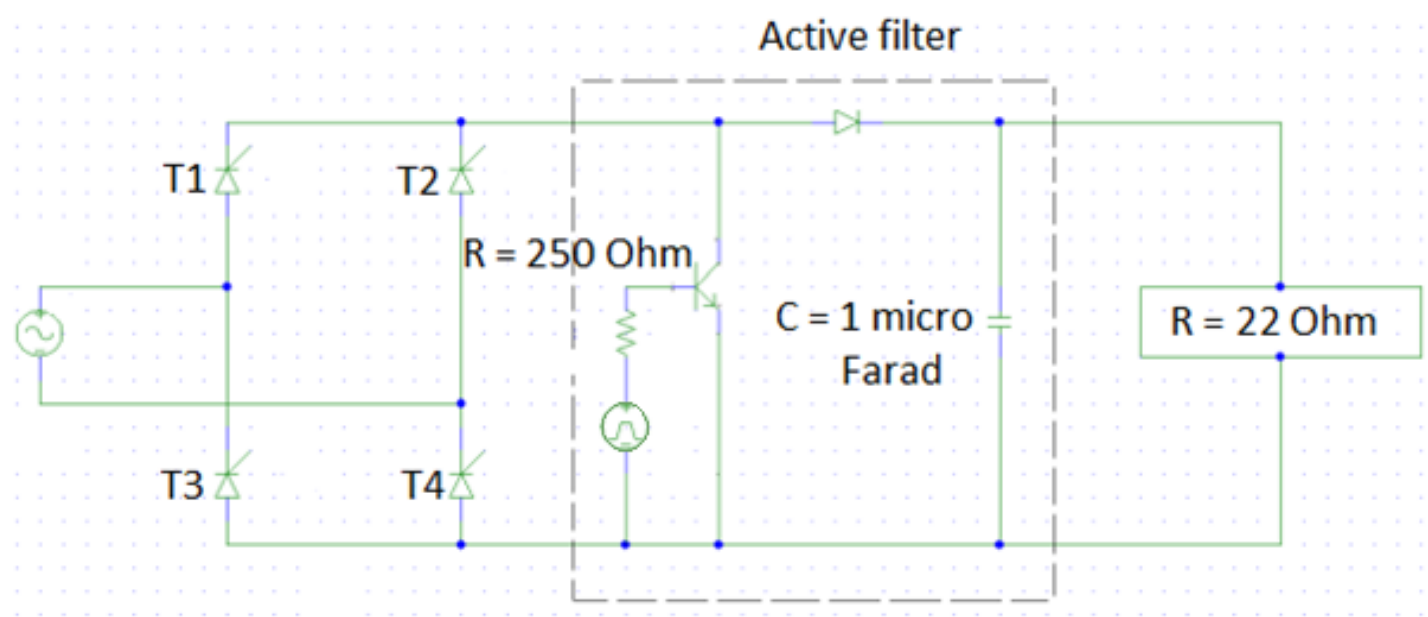

Figure 1 Schematic of the analyzed active filters.

\section{RESULTS AND DISCUSSION}

The simulation results show that there is an increase of RMS voltage and DC voltage regardless of the type of active filters used which can be seen from Figure 2 (a) and (b). Both Figure 2 (a) and (b) also depict that active filter MOSFET consumes lower RMS and DC voltage compared to active filter BJT. This shows one of the benefits of using MOSFET over BJT for active filter applications. However, Figure 2 (c) shows that active filter MOSFET has slightly higher AC voltage compared to active filter BJT at firing angle of $30^{\circ}$ to $90^{\circ}$. Nevertheless, active filter MOSFET has significantly lower AC voltage at firing angle of $0^{\circ}$. Another advantage of using MOSFET compared to BJT can also be seen from the generated ripple factor for both active filters as shown in Figure 2 (d). It is clear that active filter MOSFET has lower ripple factor at firing angle of $0^{\circ}$, yet it has comparable ripple factor with active filter $\mathrm{BJT}$ at firing angle of $30^{\circ}$ to $90^{\circ}$. 

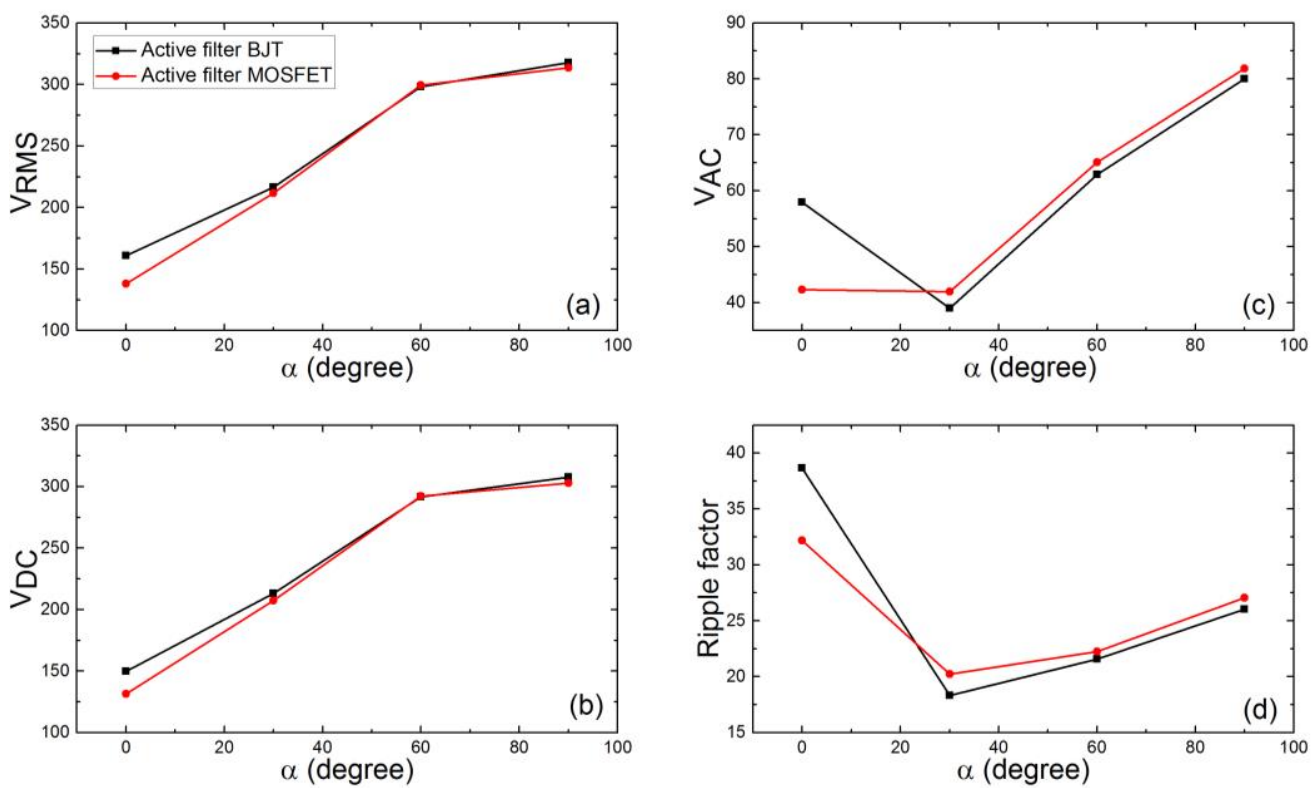

Figure 2 Voltage profile of active filter BJT and active filter MOSFET where (a) is VRMS, (b) is VDC, (c) is VAC and (d) is Ripple factor.

The efficiency of active filter MOSFET vs. active filter BJT can be analyzed by firstly examining the DC power and $\mathrm{AC}$ power of both active filters. It can be seen from Figure 3 that active filter MOSFET has lower DC power and AC power compared to active filter BJT at firing angle of $0^{\circ}, 30^{\circ}$ and $90^{\circ}$. Both active filters also have comparable DC power and $\mathrm{AC}$ power at firing angle of $60^{\circ}$. This shows that active filter MOSFET consumes lesser power compared to active filter BJT. The comparison of efficiency between these active filters can be observed in Figure 4. This figure shows that active filter MOSFET has significantly higher efficiency at firing angle of $0^{\circ}$ compared to active filter BJT. Nevertheless, active filter BJT shows slightly better efficiency at firing angle of $30^{\circ}$ to $90^{\circ}$.
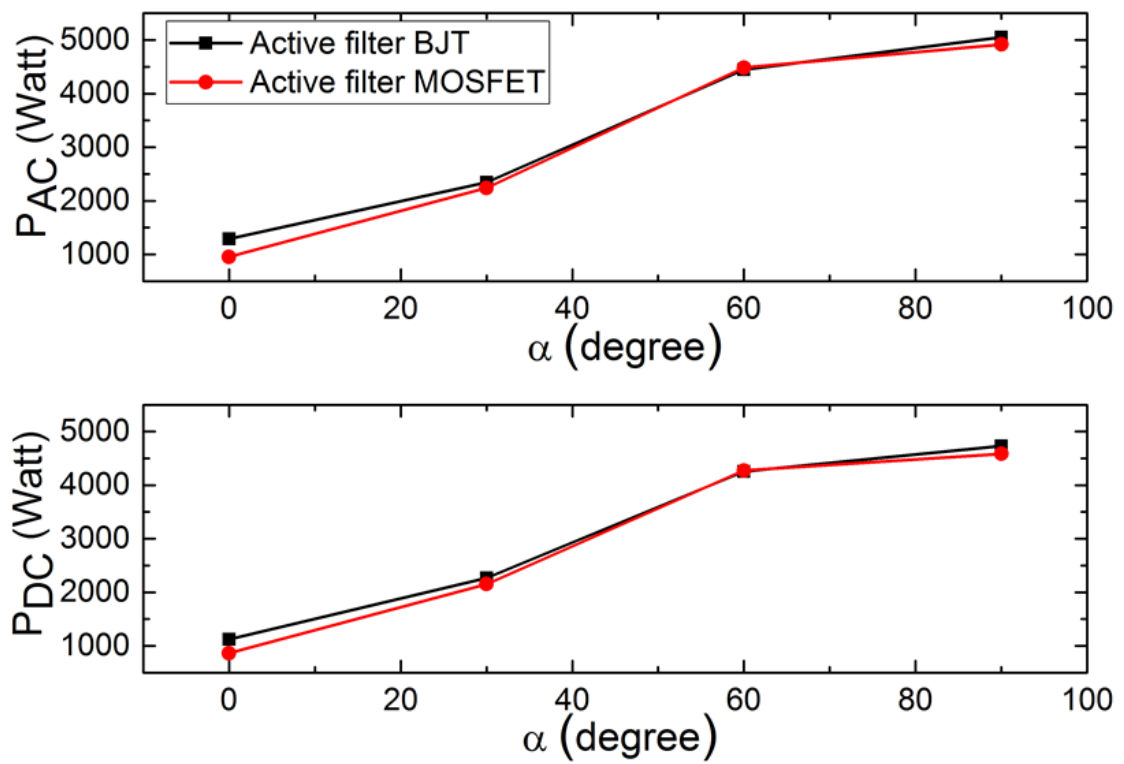

Figure 3 Power profile of active filter BJT and active filter MOSFET. (a) represents PAC and (b) denotes PDC. 


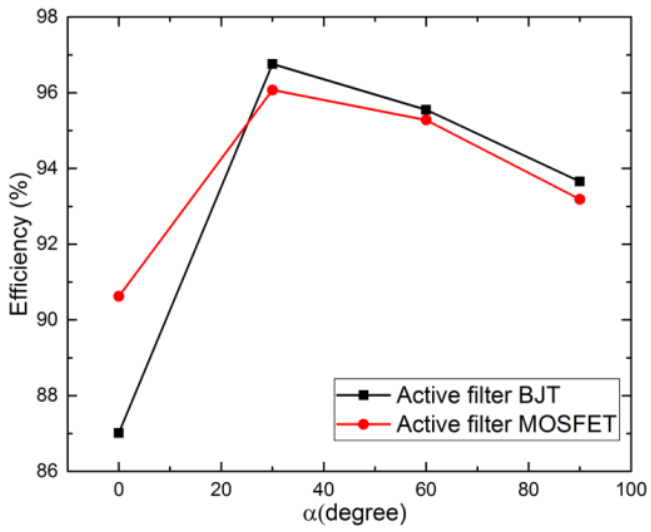

Figure 4 Efficiency of active filter BJT and active filter MOSFET.

It can be concluded from Figure 2 to Figure 4 that MOSFET active filter appears to be a better choice for a single-phase controlled rectifier application at firing angle of $0^{\circ}$, whereas there is no significant difference between both active filters at firing angle of $30^{\circ}$ to $90^{\circ}$. Therefore, it is interesting to see voltage and current waveforms of these active filters at firing angle of $0^{\circ}$. Figure 5 shows the current and voltage waveforms for active filter BJT while Figure 6 depicts those of active filter MOSFET. These two figures show that voltage and current waveforms of these two active filters are not significantly different.

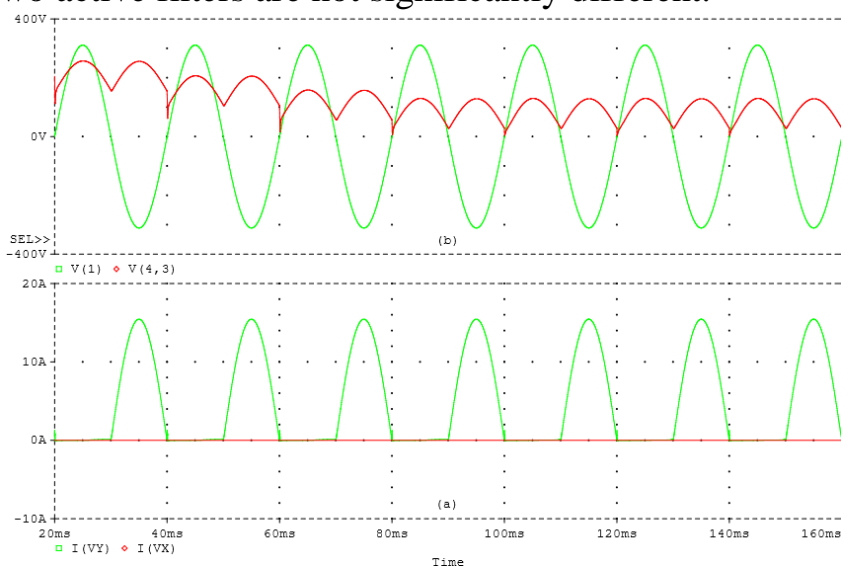

Figure 5 Input and output voltages as well as currents of active filter BJT at firing angle of $0^{\circ}$.

The input voltage and current are denoted with green lines whereas the red lines represent the output voltage and current.

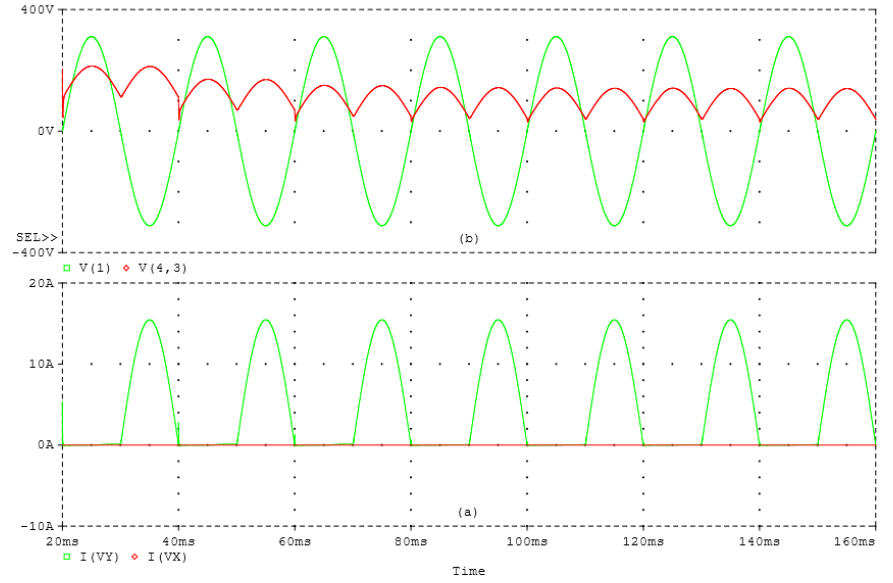

Figure 6 Input and output voltages as well as currents of active filter MOSFET at firing angle of $0^{\circ}$. 
The input voltage and current are denoted with green lines whereas the red lines represent the output voltage and current.

The RMS and average voltages waveforms of both active filters at firing angle of $0^{\circ}$ are shown in Figure 7 and Figure 8. The figures clearly show that active filter MOSFET has lower RMS and average voltage compared to active filter BJT.

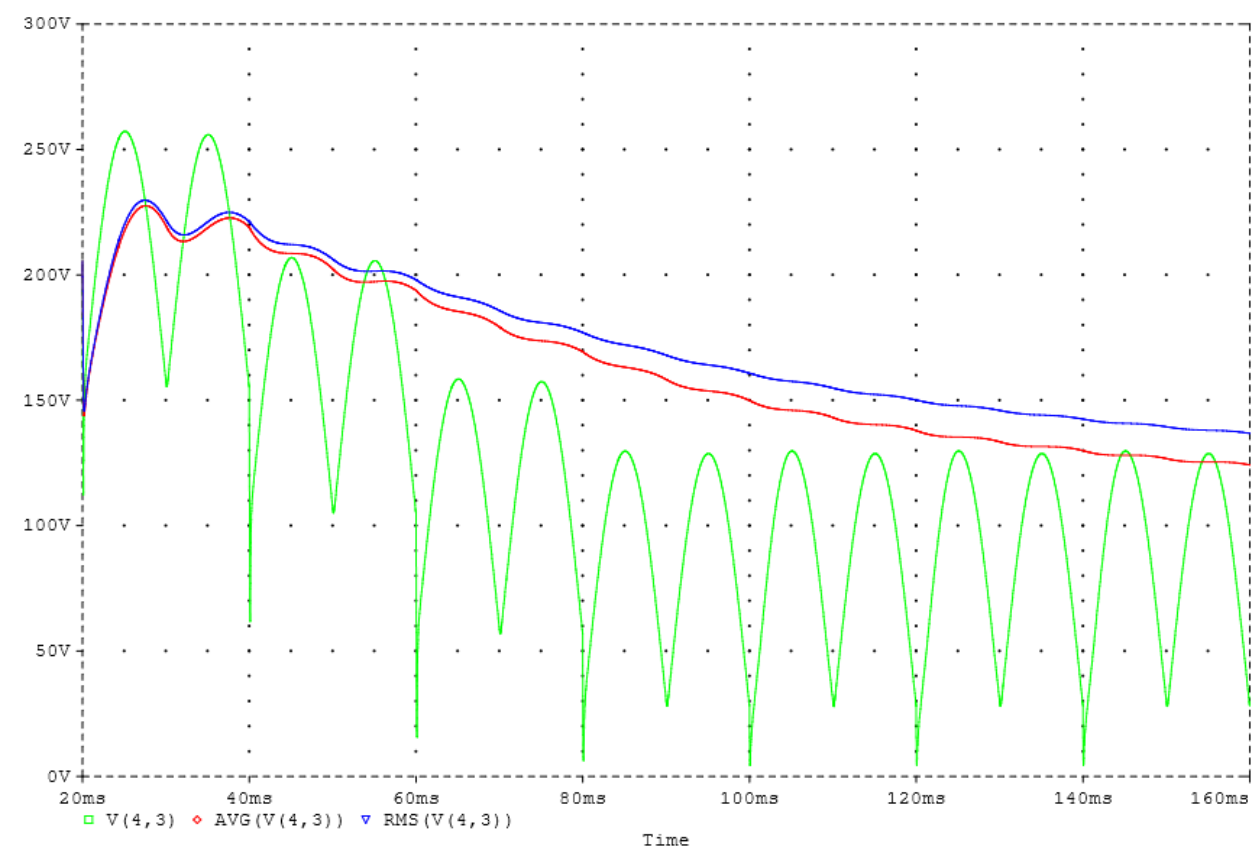

Figure 7 The voltage profile of active filter BJT at firing angle of $0^{\circ}$.

Output voltage is represented with green line, average voltage is denoted with red line and blue line represents the RMS voltage.

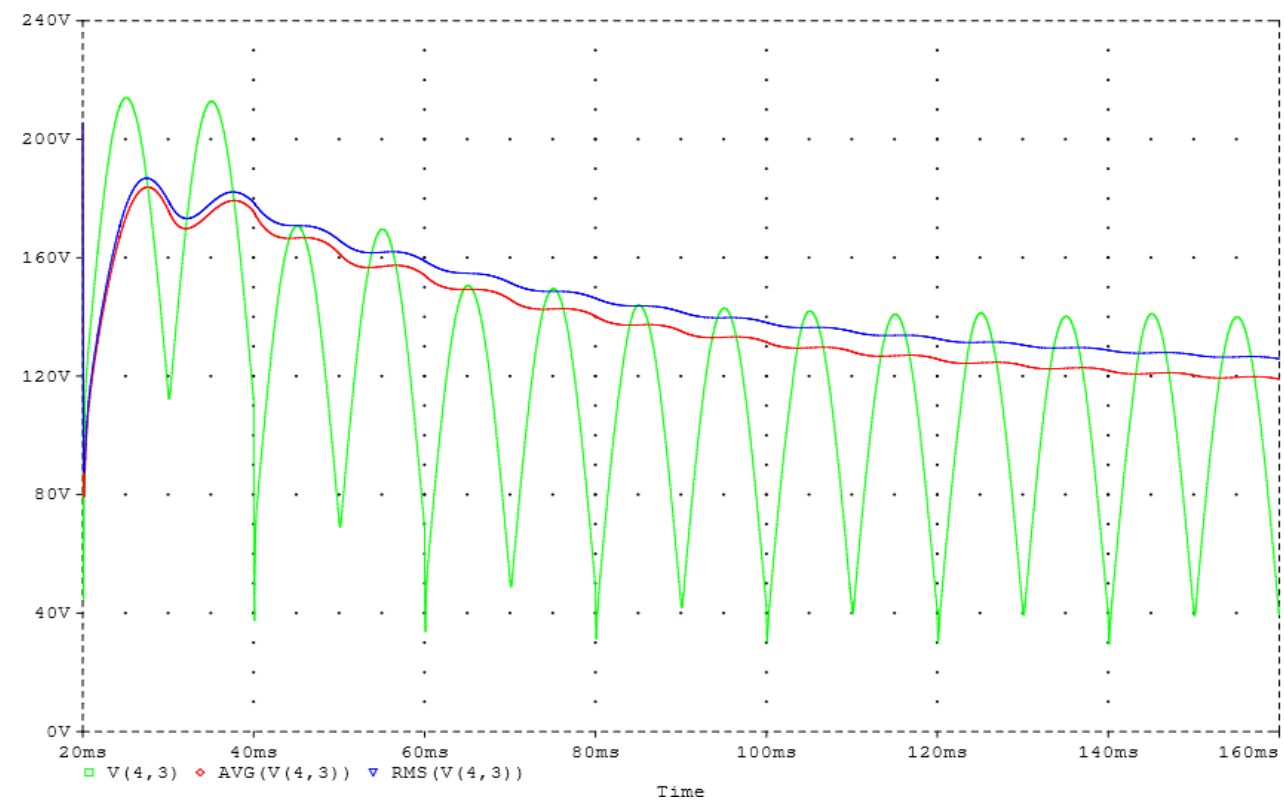

Figure 8. The voltage profile of active filter MOSFET at firing angle of $0^{\circ}$.

Output voltage is represented with green line, average voltage is denoted with red line and blue line represents the RMS voltage.

IJEIS Vol. 10, No. 2, October 2020 : 143 - 154 
The total harmonic distortions (THD) of output voltage generated by the active filter BJT and active filter MOSFET are shown in Table 1 and Table 2. It can clearly be seen that MOSFET active filter produces smaller THD compared to active filter BJT. This finding supports the fact that MOSFET active filter has better efficiency than BJT active filter at firing angle of $0^{\circ}$ as discussed earlier. The calculated power factor for both active filters are in the range of 0.57 lagging -0.92 lagging at firing angle of $0^{\circ}$ to $90^{\circ}$.

Table 1 Output voltage harmonics of BJT active filter at firing angle of $0^{\circ}$.

\begin{tabular}{|cccccr|}
\hline $\begin{array}{c}\text { HARMONIC } \\
\text { NO }\end{array}$ & $\begin{array}{c}\text { FREQUENCY } \\
(\mathrm{HZ})\end{array}$ & $\begin{array}{c}\text { FOURIER } \\
\text { COMPONENT }\end{array}$ & $\begin{array}{l}\text { NORMALIZED } \\
\text { COMPONENT }\end{array}$ & $\begin{array}{c}\text { PHASE } \\
\text { (DEG) }\end{array}$ & \multicolumn{1}{c|}{$\begin{array}{c}\text { NORMALIZED } \\
\text { PHASE }\end{array}$} \\
& & & & & \\
1 & $5.000 \mathrm{E}+01$ & $1.667 \mathrm{E}+00$ & $1.000 \mathrm{E}+00$ & $-9.713 \mathrm{E}+01$ & $0.000 \mathrm{E}+00$ \\
2 & $1.000 \mathrm{E}+02$ & $4.466 \mathrm{E}+01$ & $2.680 \mathrm{E}+01$ & $-9.433 \mathrm{E}+01$ & $2.797 \mathrm{E}+00$ \\
3 & $1.500 \mathrm{E}+02$ & $8.121 \mathrm{E}-01$ & $4.873 \mathrm{E}-01$ & $-1.780 \mathrm{E}+02$ & $-8.088 \mathrm{E}+01$ \\
4 & $2.000 \mathrm{E}+02$ & $8.565 \mathrm{E}+00$ & $5.139 \mathrm{E}+00$ & $-9.938 \mathrm{E}+01$ & $-2.257 \mathrm{E}+00$ \\
5 & $2.500 \mathrm{E}+02$ & $1.512 \mathrm{E}-01$ & $9.071 \mathrm{E}-02$ & $1.276 \mathrm{E}+02$ & $2.247 \mathrm{E}+02$ \\
6 & $3.000 \mathrm{E}+02$ & $3.783 \mathrm{E}+00$ & $2.270 \mathrm{E}+00$ & $-1.002 \mathrm{E}+02$ & $-3.050 \mathrm{E}+00$ \\
7 & $3.500 \mathrm{E}+02$ & $1.907 \mathrm{E}-01$ & $1.144 \mathrm{E}-01$ & $-1.264 \mathrm{E}+02$ & $-2.923 \mathrm{E}+01$ \\
8 & $4.000 \mathrm{E}+02$ & $2.203 \mathrm{E}+00$ & $1.322 \mathrm{E}+00$ & $-1.071 \mathrm{E}+02$ & $-9.935 \mathrm{E}+00$ \\
9 & $4.500 \mathrm{E}+02$ & $1.990 \mathrm{E}-01$ & $1.194 \mathrm{E}-01$ & $-1.595 \mathrm{E}+02$ & $-6.235 \mathrm{E}+01$ \\
\hline
\end{tabular}

TOTAL HARMONIC DISTORTION $=2.741758$ PERCENT

Table 2. Output voltage harmonics of MOSFET active filter at firing angle of $0^{\circ}$.

\begin{tabular}{|cccccr|}
\hline $\begin{array}{c}\text { HARMONIC } \\
\text { NO }\end{array}$ & $\begin{array}{c}\text { FREQUENCY } \\
(\mathrm{HZ})\end{array}$ & $\begin{array}{c}\text { FOURIER } \\
\text { COMPONENT }\end{array}$ & $\begin{array}{c}\text { NORMALIZED } \\
\text { COMPONENT }\end{array}$ & $\begin{array}{c}\text { PHASE } \\
(\mathrm{DEG})\end{array}$ & \multicolumn{1}{c|}{$\begin{array}{c}\text { NORMALIZED } \\
\text { PHASE }\end{array}$} \\
& $(\mathrm{DEG})$ & & & \\
1 & $5.000 \mathrm{E}+01$ & $3.255 \mathrm{E}+00$ & $1.000 \mathrm{E}+00$ & $-1.036 \mathrm{E}+02$ & $0.000 \mathrm{E}+00$ \\
2 & $1.000 \mathrm{E}+02$ & $4.583 \mathrm{E}+01$ & $1.408 \mathrm{E}+01$ & $-9.537 \mathrm{E}+01$ & $8.260 \mathrm{E}+00$ \\
3 & $1.500 \mathrm{E}+02$ & $1.984 \mathrm{E}+00$ & $6.094 \mathrm{E}-01$ & $-1.582 \mathrm{E}+02$ & $-5.454 \mathrm{E}+01$ \\
4 & $2.000 \mathrm{E}+02$ & $9.075 \mathrm{E}+00$ & $2.788 \mathrm{E}+00$ & $-1.052 \mathrm{E}+02$ & $-1.534 \mathrm{E}+00$ \\
5 & $2.500 \mathrm{E}+02$ & $9.107 \mathrm{E}-01$ & $2.797 \mathrm{E}-01$ & $1.791 \mathrm{E}+02$ & $2.827 \mathrm{E}+02$ \\
6 & $3.000 \mathrm{E}+02$ & $3.866 \mathrm{E}+00$ & $1.188 \mathrm{E}+00$ & $-1.099 \mathrm{E}+02$ & $-6.231 \mathrm{E}+00$ \\
7 & $3.500 \mathrm{E}+02$ & $5.558 \mathrm{E}-01$ & $1.707 \mathrm{E}-01$ & $-1.746 \mathrm{E}+02$ & $-7.092 \mathrm{E}+01$ \\
8 & $4.000 \mathrm{E}+02$ & $2.205 \mathrm{E}+00$ & $6.774 \mathrm{E}-01$ & $-1.154 \mathrm{E}+02$ & $-1.180 \mathrm{E}+01$ \\
9 & $4.500 \mathrm{E}+02$ & $3.893 \mathrm{E}-01$ & $1.196 \mathrm{E}-01$ & $-1.699 \mathrm{E}+02$ & $-6.626 \mathrm{E}+01$ \\
\hline
\end{tabular}

TOTAL HARMONIC DISTORTION $=1.443215$ PERCENT

\section{CONCLUSIONS}

The performance of active filters based on BJT and MOSFET has been comprehensively analyzed and compared. It is intriguing to see that active filter MOSFET appears to be a more efficient choice compared to active filter BJT that can be seen from the lower RMS and DC voltages consumed by active filter MOSFET compared to those of active filter BJT. Similarly, active filter MOSFET shows significantly lower fipple voltage at firing angle of $0^{\circ}$. These results are also in agreement with the consumed AC and DC powers of active filter MOSFET which are obviously smaller at firing angle of $0^{\circ}$. The calculated efficiency also shows that active filter MOSFET has significantly higher efficiency compared to active filter BJT at firing angle of $0^{\circ}$ which is also aligned with the lower THD generated by this active filter. However, both active filters show comparable performances at firing angles of $30^{\circ}$ to $90^{\circ}$. Therefore, MOSFET active filter is suggested to be used at firing angle of $0^{\circ}$. However, either active filters can be used when the single-phase controlled rectifier is fired at firing angle of $30^{\circ}$ to $90^{\circ}$. It is expected that this work can provide useful insights for the design of active filters in recent technological developments in various applications of power electronics. 


\section{ACKNOWLEDGEMENTS}

The authors would like to acknowledge financial support provided by Universitas Buddhi Dharma for this research.

\section{REFERENCES}

[1] Z. Zhang, Z. Li, M. P. Kazmierkowski, J. Rodriguez, and R. Kennel, "Robust predictive control of three-level NPC back-to-back power converter PMSG wind turbine systems with revised predictions," IEEE Transactions on Power Electronics, vol. 33, pp. 9588-9598, 2018 [online]. Available: https://ieeexplore.ieee.org/abstract/document/8267139. [Accessed: 05November-2019].

[2] U. Radhakrishna, P. Riehl, N. Desai, P. Nadeau, Y. Yang, A. Shin, et al., "A low-power integrated power converter for an electromagnetic vibration energy harvester with $150 \mathrm{mV}$-AC cold startup, frequency tuning, and $50 \mathrm{~Hz}$ AC-to-DC conversion," in 2018 IEEE Custom Integrated Circuits Conference (CICC), 2018, pp. $1-4 \quad$ [online]. Available: https://ieeexplore.ieee.org/abstract/document/8357079/ [Accessed: 08November-2019].

[3] M.-D. Wei, Y.-T. Chang, D. Wang, C.-H. Tseng, and R. Negra, "Balanced RF rectifier for energy recovery with minimized input impedance variation," IEEE Transactions on Microwave Theory and Techniques, vol. 65, pp. 1598-1604, 2017 [online]. Available: https://ieeexplore.ieee.org/abstract/document/7827056/ [Accessed: 10-November-2019].

[4] J. C. Hertel, J. E. F. Overgaard, I. H. H. Jørgensen, T. M. Andersen, M. Rødgaard, and A. Knott, "Synchronous Rectifier for High-Frequency Switch Mode Power Supplies using Phase Locked Loops," IEEE Journal of Emerging and Selected Topics in Power Electronics, 2019 [online]. Available: https://ieeexplore.ieee.org/abstract/document/8859287/ [Accessed: 12December-2019].

[5] J. Bae, H. Koo, H. Lee, W. Lim, W. Lee, H. Kang, et al., "High-efficiency rectifier $(5.2 \mathrm{GHz})$ using a C lass-FD ickson charge pump," Microwave and Optical Technology Letters, vol. 59, pp. 3018-3023, 2017 [online]. Available: https://onlinelibrary.wiley.com/doi/abs/10.1002/mop.30862 [Accessed: 18December-2019].

[6] P. Huynh and A. Banerjee, "Integrated Generator-Rectifier for Electric Ship DC Power System," in 2019 IEEE Electric Ship Technologies Symposium (ESTS), 2019, pp. 592-598 [online]. Available: https://ieeexplore.ieee.org/abstract/document/8847809/ [Accessed: 01-January2020].

[7] D. Mukherjee and D. Kastha, "A reduced switch hybrid multilevel unidirectional rectifier," IEEE Transactions on Power Electronics, vol. 34, pp. 2070-2081, 2018 [online]. Available: https://ieeexplore.ieee.org/abstract/document/8359189 [Accessed: 07-January-2019].

[8] Y. Guo, G. Wang, D. Zeng, H. Li, and H. Chao, "A thyristor full-bridge-based DC circuit breaker," IEEE Transactions on Power Electronics, vol. 35, pp. 
1111-1123,

Available: https://ieeexplore.ieee.org/abstract/document/8710303/ [Accessed: 20-January2020].

[9] L. Wang, C.-S. Lam, and M.-C. Wong, "Design of a thyristor controlled LC compensator for dynamic reactive power compensation in smart grid," IEEE Transactions on Smart Grid, vol. 8, pp. 409-417, 2016 [online]. Available: https://ieeexplore.ieee.org/abstract/document/7486136/ [Accessed: 22-Februari2020].

[10] M. Lee, J.-W. Kim, J.-M. Choe, and J.-S. Lai, "Design of Repetitive Controller and Input Filter for Active Front-End Rectifier in Solid-State Transformer Under Finite Harmonics and Source Impedance," in 2018 Asian Conference on Energy, Power and Transportation Electrification (ACEPT), 2018, pp. 1-7 [online]. Available: https://ieeexplore.ieee.org/abstract/document/8610659/ [Accessed: 01-Maret-2020].

[11] M. H. Gowda and K. Vinayaka, "Three-Phase Shunt Active Filter for Cuk-Sepic Fused Converter with Solar-Wind Hybrid Sources," in Emerging Research in Electronics, Computer Science and Technology, ed: Springer, 2019, pp. 11991210 [online]. Available: https://link.springer.com/chapter/10.1007/978-981-135802-9_103 [Accessed: 18-Maret-2020].

[12] T. Huynh, L. Minh, C. Van Ho, X. Tien Nguyen, and T. Vu Tran, "Improving the Adaptive Effecting for Active Power Filter Using Fuzzy Control in the DC Link Voltage's Stability Controller," International Journal of Mechanical Engineering and Technology, vol. 10, 2019 [online]. Available: https://papers.ssrn.com/sol3/papers.cfm?abstract_id=3453031 [Accessed: 01April-2020].

[13] P. L. Chavan and S. K. Nayak, "Active Power Filters to Reduce Harmonics and Improve Power Quality," IUP Journal of Electrical \& Electronics Engineering, vol. $12, \quad 2019 . \quad$ [online]. Available: https://web.a.ebscohost.com/abstract?direct=true \&profile=ehost\&scope=site \&au thtype $=$ crawler $\& \mathrm{jrnl}=09741704 \& \mathrm{AN}=136530709 \& \mathrm{~h}=\% 2 \mathrm{fMBin} 3 \mathrm{Y} 7 \mathrm{VC} 9 \mathrm{yDr} 5 \mathrm{~K}$ fzFZ715QrXT2yelIjan\%2bO02Fqs1LUf0TJNXTpYubkIttnXBiBktPFJ253oZifX uOnheHUw\%3d\%3d\&crl=c\&resultNs=AdminWebAuth\&resultLocal=ErrCrlNo tAuth\&crlhashurl=login.aspx \%3fdirect\%3dtrue \%26profile\%3dehost $\% 26$ scope 3 dsite\%26authtype\%3dcrawler\%26jrnl\%3d09741704\%26AN\%3d136530709 [Accessed: 01-April-2020].

[14] M. Diab, M. El-Habrouk, T. Abdelhamid, and S. Deghedie, "Survey of active power filters configurations," in 2018 IEEE International Conference on System, Computation, Automation and Networking (ICSCA), 2018, pp. 1-14 [online]. Available: https://ieeexplore.ieee.org/abstract/document/8541225/ [Accessed: 07-April-2020].

[15] S. Biricik, O. C. Ozerdem, S. Redif, and M. S. Dincer, "New hybrid active power filter for harmonic current suppression and reactive power compensation," International Journal of Electronics, vol. 103, pp. 1397-1414, 2016 [online].

https://www.tandfonline.com/doi/abs/10.1080/00207217.2015.1116113 [Accessed: 15-April-2020].

[16] A. Amerise, M. Mengoni, G. Rizzoli, L. Zarri, A. Tani, and D. Casadei, "Comparison of Three Voltage Saturation Algorithms in Shunt Active Power 
Filters With Selective Harmonic Control," IEEE Transactions on Industry Applications, vol. 56, pp. 2762-2772, 2020 [online]. Available: https://ieeexplore.ieee.org/document/8988204/ [Accessed: 29-October-2020].

[17] A. K. Mishra, S. R. Das, P. K. Ray, R. K. Mallick, A. Mohanty, and D. K. Mishra, "PSO-GWO Optimized Fractional Order PID Based Hybrid Shunt Active Power Filter for Power Quality Improvements," IEEE Access, vol. 8, pp. 74497-74512, 2020 [online]. Available: https://ieeexplore.ieee.org/document/9069960/ [Accessed: 29-October-2020].

[18] J. Han, S. Zheng, G. Yao, H. Chen, Y. Wang, and T. Tang, "Multiple Harmonic Current Injection System for Audible Noise Analysis of AC Filter Capacitors in Converter Stations," IEEE Access, vol. 8, pp. 94024 - 94032, 2020 [online]. Available: https://ieeexplore.ieee.org/document/9090189 [Accessed: 29October-2020].

[19] M. Kashif, M. Hossain, E. Fernandez, S. Taghizadeh, V. Sharma, S. N. Ali, et al., "A Fast Time-Domain Current Harmonic Extraction Algorithm for Power Quality Improvement Using Three-Phase Active Power Filter," IEEE Access, vol. $8, \quad$ pp. 103539-103549, 2020 [online]. Available: ieeexplore.ieee.org/document/9105002 [Accessed: 29-October-2020].

[20] S. Kundu, S. Banerjee, and S. Bhowmick, "Improved SHM-PAM-based fivelevel CHB inverter to fulfil NRS 048-2: 2003 grid code and to apply as shunt active power filter with tuned proportional-resonant controller for improving power quality," IET Power Electronics, vol. 13, pp. 2350-2360, 2020 [online]. Available: https://ieeexplore.ieee.org/document/9176876 [Accessed: 29October-2020].

[21] H. Zhai, F. Zhuo, C. Zhu, H. Yi, Z. Wang, R. Tao, et al., "An optimal compensation method of shunt active power filters for system-wide voltage quality improvement," IEEE Transactions on Industrial Electronics, vol. 67, pp. 1270-1281, 2019 [online]. Available: https://ieeexplore.ieee.org/document/8648401 [Accessed: 29-October-2020].

[22] M. Alhasheem, P. Mattavelli, and P. Davari, "Harmonics Mitigation and NonIdeal Voltage Compensation Utilizing Active Power Filter Based On Predictive Current Control," IET Power Electronics, vol. 13, pp. 2782 - 2793, 2020 [online]. Available: https://ieeexplore.ieee.org/document/9225251 [Accessed: 29-October-2020].

[23] P. K. Ray and S. D. Swain, "Performance enhancement of shunt active power filter with the application of an adaptive controller," IET Generation, Transmission \& Distribution, vol. 14, pp. 4444-4451, 2020 [online]. Available: https://ieeexplore.ieee.org/document/9205047 [Accessed: 29-October-2020].

[24] Z. Cui, C. Li, W. Dai, L. Zhang, and Y. Wu, "A Hierarchical TeachingLearning-Based Optimization Algorithm for Optimal Design of Hybrid Active Power Filter," IEEE Access, vol. 8, pp. 143530-143544, 2020 [online]. Available: https://ieeexplore.iee.org/document/9097257 [Accessed: 29October-2020].

[25] P. Santiprapan, A. Booranawong, K. Areerak, and H. Saito, "An Adaptive Repetitive Controller for an Active Power Filter in Three-Phase Four-Wire Systems," IET Power Electronics, vol. 13, pp. 2756 - 2766, 2020 [online]. Available: https://digital-library.theiet.org/content/journals/10.1049/ietpel.2019.1401?crawler=redirect [Accessed: 29-October-2020]. 
[26] H. Akagi, "Active harmonic filters," Proceedings of the IEEE, vol. 93, pp. 21282141, 2005 [online]. Available: https://ieeexplore.ieee.org/abstract/document/1545766/ [Accessed: 15-April2020].

[27] H. Akagi and K. Isozaki, "A hybrid active filter for a three-phase 12-pulse diode rectifier used as the front end of a medium-voltage motor drive," IEEE transactions on power Electronics, vol. 27, pp. 69-77, 2011 [online]. Available: https://ieeexplore.ieee.org/abstract/document/5776686 [Accessed: 20-April2020].

[28] W. U. K. Tareen and S. Mekhielf, "Three-phase transformerless shunt active power filter with reduced switch count for harmonic compensation in gridconnected applications," IEEE Transactions on Power Electronics, vol. 33, pp. 4868-4881, 2017 [online]. Available: https://ieeexplore.ieee.org/abstract/document/7983380 [Accessed: 20-April2020].

[29] L. Tarisciotti, A. Formentini, A. Gaeta, M. Degano, P. Zanchetta, R. Rabbeni, et al., "Model predictive control for shunt active filters with fixed switching frequency," IEEE Transactions on Industry Applications, vol. 53, pp. 296-304, 2016 [online]. Available: https://ieeexplore.ieee.org/abstract/document/7562477/ [Accessed: 25-April-2020].

[30] B. Madhu, D. Mn, and R. Bm, "Design of shunt hybrid active power filter (SHAPF) to reduce harmonics in AC side due to Non-linear loads," International Journal of Power Electronics and Drive Systems, vol. 9, p. 1926, 2018 [online].

Available: https://pdfs.semanticscholar.org/fcfa/4db1607d3c957e0027464f5a34d142f69ceb .pdf [Accessed: 01-Mei-2020].

[31] E. Guest, K. H. Jensen, and T. W. Rasmussen, "Mitigation of Harmonic Voltage Amplification in Offshore Wind Power Plants by Wind Turbines with Embedded Active Filters," IEEE Transactions on Sustainable Energy, vol. 11, pp. $785 \quad$ - $7942019 . \quad$ [online]. Available: https://ieeexplore.ieee.org/abstract/document/8672500 [Accessed: 01-Mei2020].

[32] M. Zubiaga, A. Sanchez-Ruiz, E. Olea, J. X. Balenciaga, D. Madariaga, and J. Arza, "Reactive power boundaries for a MV STATCOM with harmonic active filter capability," in IECON 2019-45th Annual Conference of the IEEE Industrial Electronics Society, 2019, pp. 6172-6177 [online]. Available: https://ieeexplore.ieee.org/abstract/document/5776686/ [Accessed: 01-Mei2020].

[33] R. Sahu, A. Jha, and V. K. Sahu, "Hybrid Active Power Filter Topologies for Power Quality Improvement: A Review," International Research Journal of Engineering and Technology, vol. 4, pp. 699-706, 2019 [online]. Available: https://www.irjet.net/archives/V2/i4/Irjet-v2i4108.pdf [Accessed: 03-Mei-2020].

[34] I.-S. Kim, Y.-H. Chun, and S.-W. Yun, "Analysis of a novel active capacitance circuit using BJT and its application to RF bandpass filters," in IEEE MTT-S International Microwave Symposium Digest, 2005., 2005, p. 4 [online]. Available: https://ieeexplore.ieee.org/abstract/document/1517190 [Accessed: 05Mei-2020]. 
[35] S. Jeong, D. Shin, and J. Kim, "A Transformer-Isolated Common-Mode Active EMI Filter Using a Low-cost BJT Amplifier with Feedforward Structure," in 2019 10th International Conference on Power Electronics and ECCE Asia (ICPE 2019-ECCE Asia), 2019, pp. 2088-2094 [online]. Available: https://ieeexplore.ieee.org/abstract/document/8797056/ [Accessed: 05-Mei2020]. 